\title{
БАГАНУУР, ТАВАНТОЛГОЙН НУУРСНИЙ ТЕРМОГРАФИ, ТЕРМОЛИЗИЙН СУДАЛГАА
}

\author{
Ю.Д. Каминский ${ }^{1}$, Ж.Дугаржав ${ }^{2}$, Т.Е.Шоева ${ }^{1}$, Б.Авид \\ ${ }^{I}$ - Ново-Сибирск, Хатуу биеийн хими, механохимийн хүрээлэн; \\ 2 - Улаанбаатар, ШУА-ийн Хими, хими-технологийн хүрээлэн \\ Цахим шуудан:dugar21mn@yahoo.com,avid_icct@yahoo.com
}

\section{ОРШИЛ}

Нийлэг түлш, кокс химийн аж үйлдвэрийг үүсгэн хөгжүүлэх зорилт тавигдаж байгаа өнөө үед Багануур, Тавантолгой мэтийн томоохон ордуудын нүүрсний хими - бүтцийн төрх байдал, урвалын идэвх, ялангуяа, халуун задрал, хийгээд механохимийн урвалыг гүнзгий судлах нь ихээхэн ач холбогдолтой. Нөгөө талаар, багануур ба тавантолгойн нүүрс бол Монгол орны хүрэн ба коксждог чулуун нүүрсний түгээмэл төлөөлөгч тул бусад ордын ижил төсөөтөй нүүрсний төрх байдлын үнэлгээнд ч хөрвүүлэн ашиглах боломжтой. Энэ үҮднээс бид ОХУ - Ын ШУА - ийн Сибирийн салбар, Монголын ШУАийн хамтарсан төслийн хүрээнд хоёр ордын нүүрсний хими- бүтцийн гүнзгийрүүлсэн судалгаа явуулсан бөгөөд өмнөх өгүүлэлд /1/ хоёр ордын нүүрсний петрограф, морфологи болон химийн байгуулалтын судалгааны үр дүнгүүдийг гаргасан болно. Энэ өгүүлэлд хоёр ордын нүүрсний термографи, термолиз, механохимийн судалгааны дүнгүүдийг өгүүлэв.

\section{СУДАЛГААНЫ МАТЕРИАЛ БА АРГА ЗУЙ}

Судалгааг

Багануурын

ордын уулын 1-p хэсэг, Тавантолгойн ордын 4 ба 8-p давхраасын нүүрсний дээжүүд дээр явуулсан, дээжийг орд-уурхайн ил мөрөгцгөөс ховилын аргаар авсан. Нүурсний дээжүүдийн ДТА ( differential thermal analysis, DTA)- $\Gamma$ DSC Netzsch 204 F1 Phoenix калориметрээр 300 725 К температурт 5 К мин ${ }^{-1}$ хурдтай халааж 723.3К-д 1 цаг байлгаж авсан. Температурын тохируулгыг стандарт элементүудийн [ In (430,1K), Sn (505,3K), Bi (544,7K), Zn (692,3K) ] хайлах температурын дотоод зэрэгцүүлсэн хэмжилтийн аргаар хийсэн / 2,3 /. Термографийн судалгааг Унгарын Паулик, Паулик-Эрдей-1000 маркийн дериватограф дээр халаалтын 10 ${ }^{0} \mathrm{C} /$ мин хурдтай явуулсан, дээжийн ширхэг $\leq 1$ мм, тигль нь кварц байв.

\section{СУДАЛГААНЫ ҮР ДУНГИЙН ХЭЛЭЛЦУУЛЭГ \\ Дээжүүдийн үндсэн үзүүлэлтийг 1-p хүснэгтэд үзүүлэв.}

ХУснэгт 1

Багануур, Тавантолгойн нүүрсний Үндсэн ҮзҮҮлэлт

\begin{tabular}{|c|l|c|c|c|c|c|}
\hline \multirow{2}{*}{$№$} & Дээжүүд & $\begin{array}{c}\text { Чийг } \\
\mathrm{W}^{\mathrm{a}}, \%\end{array}$ & $\begin{array}{c}\text { Үнслэг } \\
\mathrm{A}^{\mathrm{d}}, \%\end{array}$ & $\begin{array}{c}\text { Дэгдэмхий } \\
\mathrm{V}^{\text {daf }} \%\end{array}$ & $\begin{array}{c}\text { Хүхэр } \\
\mathrm{S}^{\mathrm{a}}, \%\end{array}$ & $\begin{array}{c}\text { Илчлэг } \\
\mathrm{Q}, \text { ккал/кг }\end{array}$ \\
\hline 1 & Багануурын уулын 1-p хэсэг & 8.4 & 14.7 & 41.1 & 0.38 & 5034.4 \\
\hline 2 & Тавантолгой 4-р давхраас & 1.0 & 14.7 & 30.1 & 0.67 & 6828.3 \\
\hline 3 & Тавантолгой 8-р давхраас & 1.0 & 15.5 & 35.8 & 0.69 & 6763.3 \\
\hline
\end{tabular}

Энэ хүснэгт ба өмнө судлаачдын хийсэн судалгаануудын дүнгээс /4,5/ үзвэл, Багануурын нүүрс Б2 маркийн нягт хүрэн, Тавантолгойн 4 - p давхраасынх ОХУ - ын сав газрын ангилалаар КЖ (коксовый жирный) 8 - р давхраасынх СС (сул бөсөх) нүүрсний ангилалд хамаарагдана. 
Ордуудын нүүрсний ДТА

DSC Netzsch 204 F1 Phoenix калориметрээр авсан ДТА муруйнуудыг 1 - ээс 3 - р зурагт, термолизийн туршилтын дүнгүҮдийг 1 - 3 Үзүүлэв . Судалгааны энэ шатанд эгэл ба механоидэвхжүүлсэн нүүрсний ДТА - г авч харьцуулж үзсэн. Муруйнуудаас үзвэл, идэвхжүүлсэн нүүрсний дулааны процессууд арай бага температурт явагддаг нь тодорхой байна. Мөн температурын шинэ, шинэ илрэлүүд ч бүртгэгджээ.

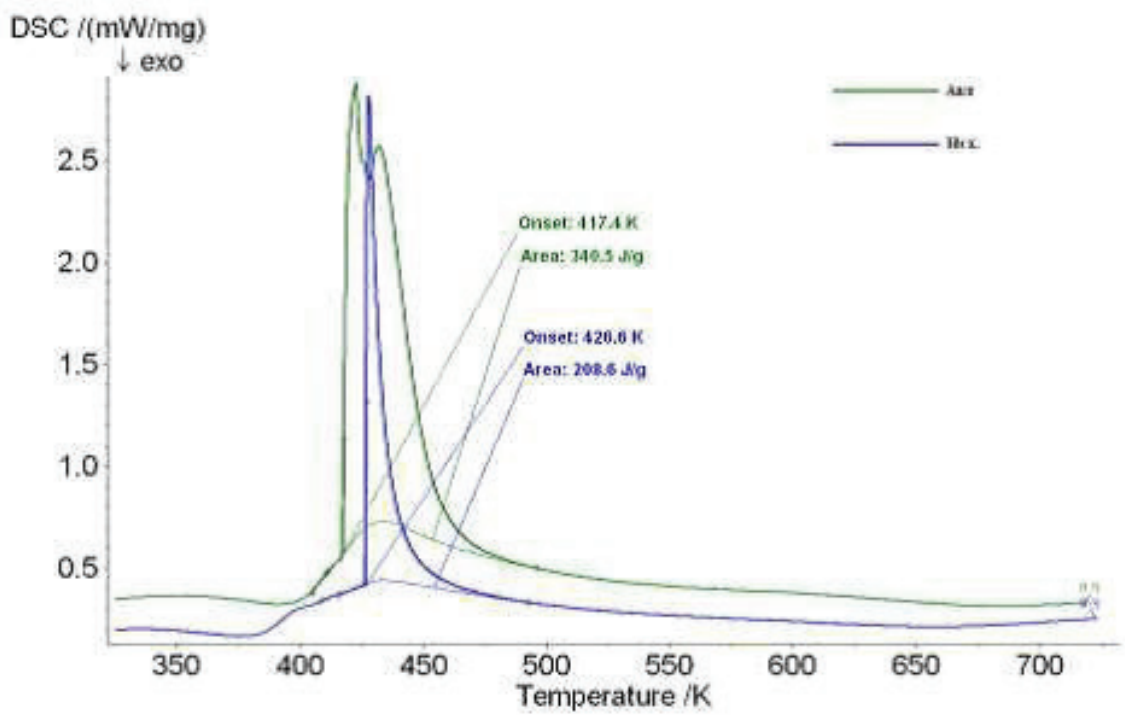

Зураг 1. Багануурын нҮҮрсний ДТА муруй

Энд: хөхөөр зурсан нь эгэл, ногооноор зурсан нь идэвхжүүлсэн нүҮрс, onset - оргил иэг, areaталбай, DSC - дулааны дифференциал анализ ДТА.

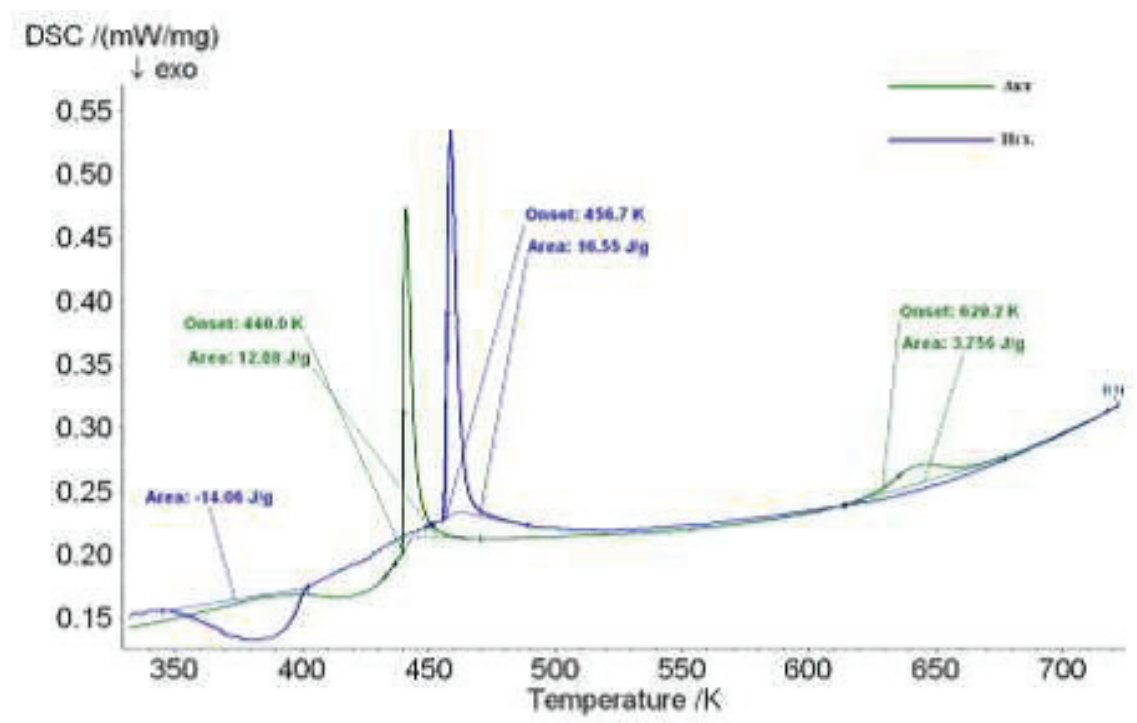

Зураг 2. Тавантолгойн 4-р давхраасын нүҮрсний ДТА муруй 


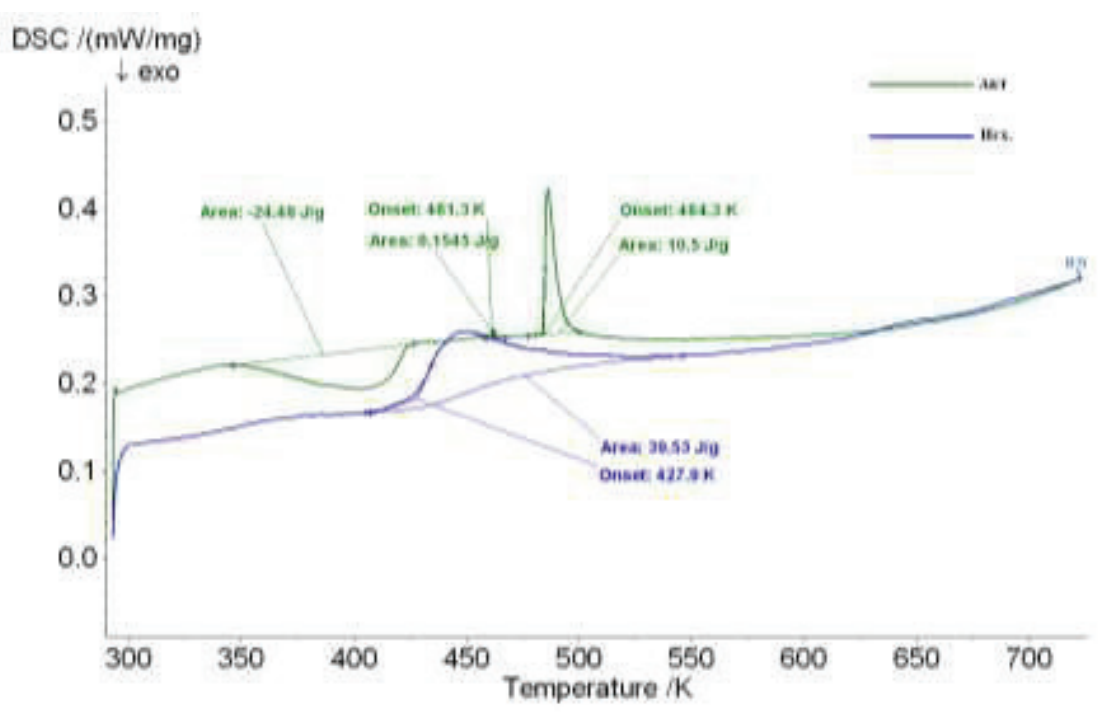

Зураг 3. Тавантолгойн 8 - р давхраасын нүүрсний ДТА муруй

Ордуудын нүүрсний термограммуудыг 4 - өөс 10 - р зургуудад, термолизийн өгөгдөхүүнийг 1 - ээс 3 - р хүснэгтүүдэд үзүүллээ.

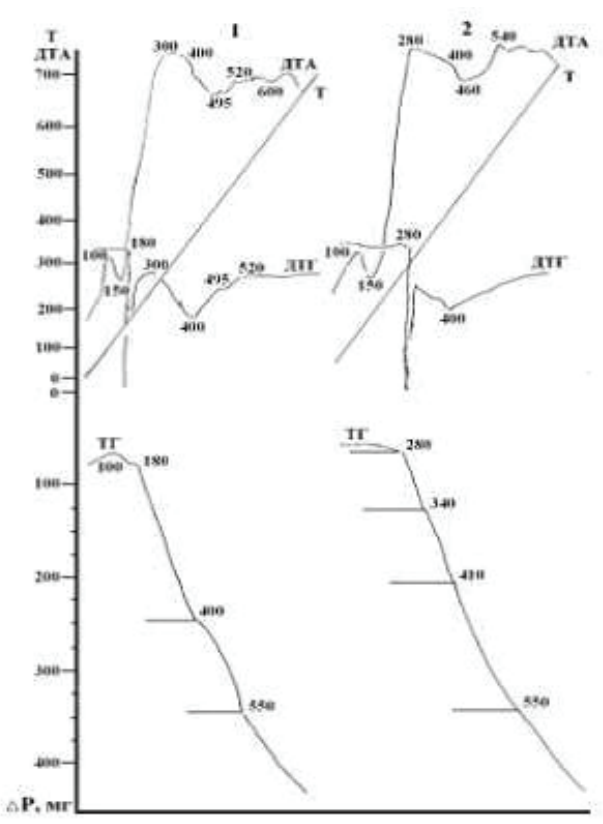

Зураг 4. Багануурын нүҮрсний термограмм (1,2 - р туршилт)

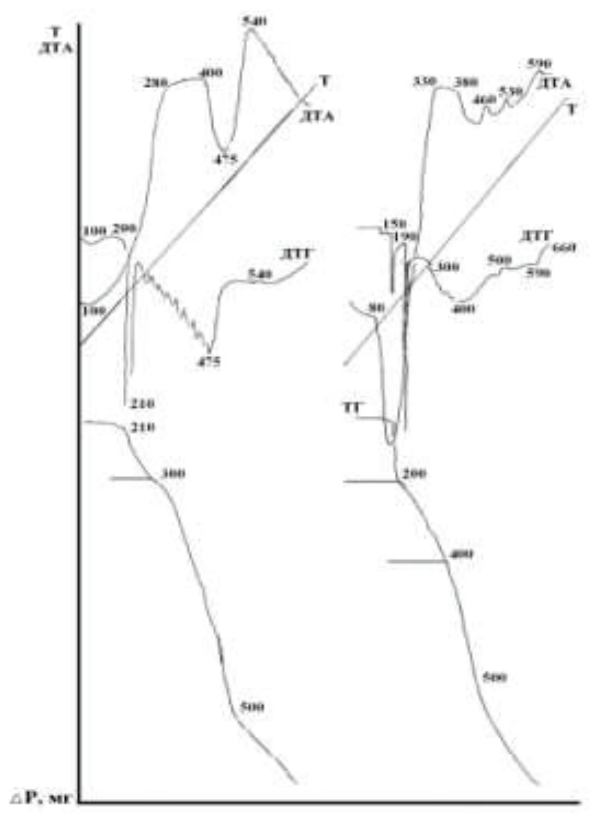

Зураг 5. Багануурын нүүрсний термограмм (3, 4-р туршилт) 


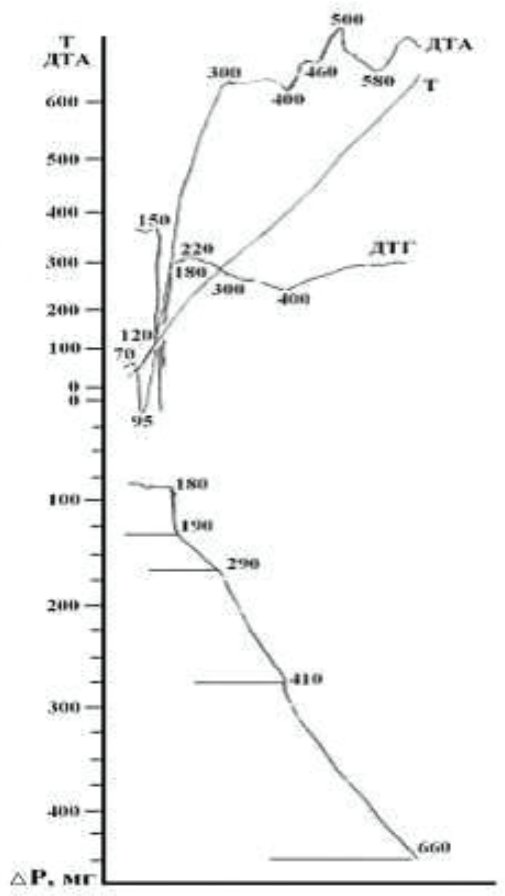

Зураг 6. Багануурын идэвхжүүлсэн нҮҮрсний термограмм (5 - р туршилт)

Багануурын эгэл нүүрстэй 4 паралель туршилт явуулсан. Термограммуудын хооронд бага зэргийн ялгаа байгаа боловч бүхэлдээ ижил бөгөөд нэгэн утгаар тайлбарлах боломжтой. Задралын процесс харьцангуй нам температур $180-210^{\circ} \mathrm{C}-$ д тэсрэлт байдлаар хий ялгаруулан эхэлдэг, ( зөвхөн $2-$ р туршилтад $180^{\circ} \mathrm{C}$ байсан ) ба эндээс үндсэн задрал эхлэх $280-300^{\circ} \mathrm{C}$ хүртэл гарах жингийн алдагдал буюу ялгарах дэгдэмхийн гарц 7\% орчим байна. Харин туршилтын төгсгөлийн температур $700{ }^{\circ} \mathrm{C}$ хүртэл ялгарах дэгдэмхийн нийлбэр 36.1 - 42.5\% байв. Механоидэвхжүүлсэн нүүрсний задрал (5 - р туршилт ) мөн л харьцангуй нам температур $180-200{ }^{\circ} \mathrm{C}$ - д эхэлж үндсэн задрал эхлэх хүртэлхи жингийн алдагдал $8-9 \%$, төгсгөлийн 600 ба $660{ }^{\circ} \mathrm{C}$ хүртэлхи алдагдал $38.5 \%$ хүрсэн. 


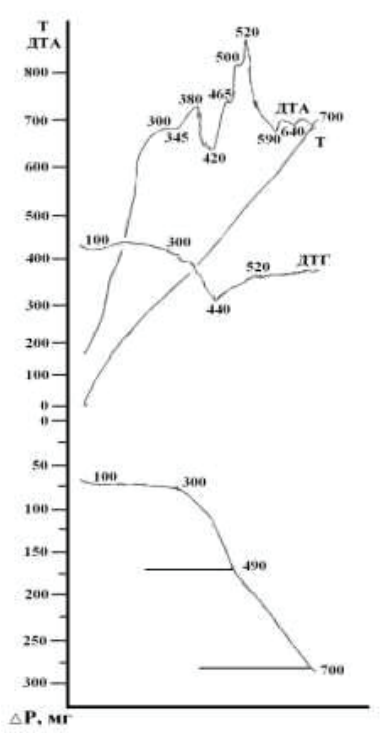

Зураг 7. Тавантолгойн 4 - $p$ давхраасын эгэл нүҮрсний термограмм (6 - р туршилт)

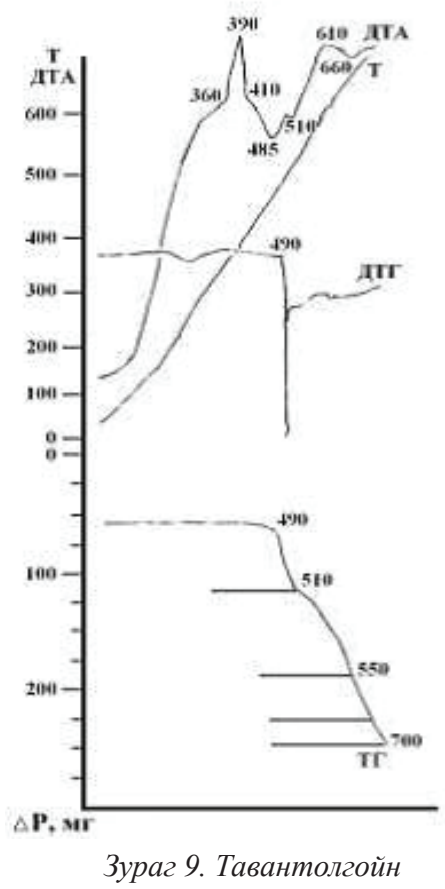

$8-p$ давхраасын нүҮрсний термограмм (9-р туршилт)
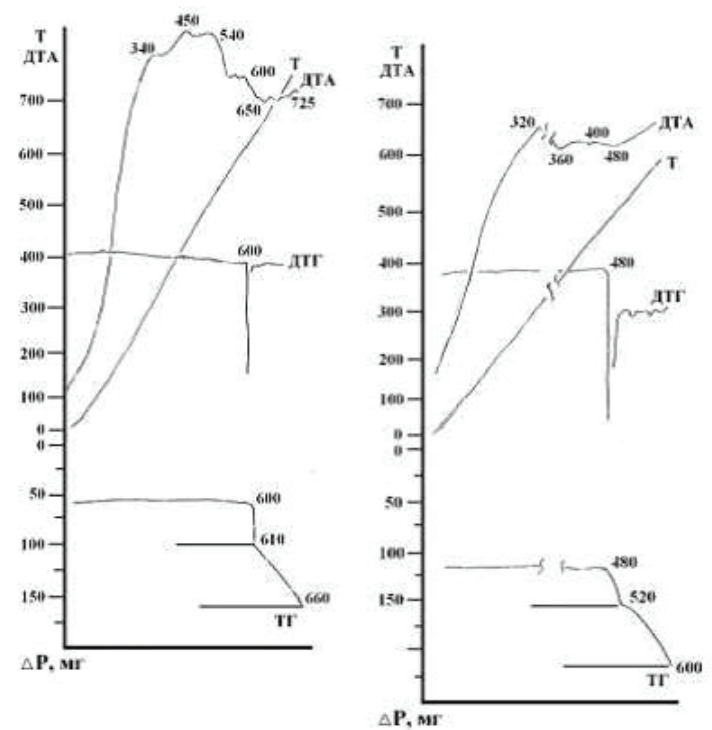

Зураг 8. Тавантолгойн 4-р давхраасын идэвхжүүлсэн нҮҮрсний термограмм (7,8-р туршилт)

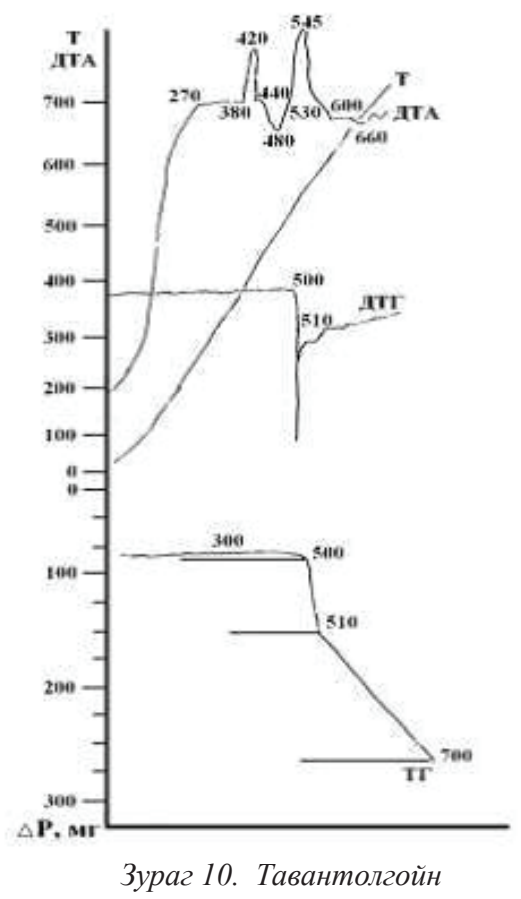

8 - $р$ давхраасын идэвхжүүлсэн нүүрсний термограмм (10 - р туршилт) 
ㄴ.

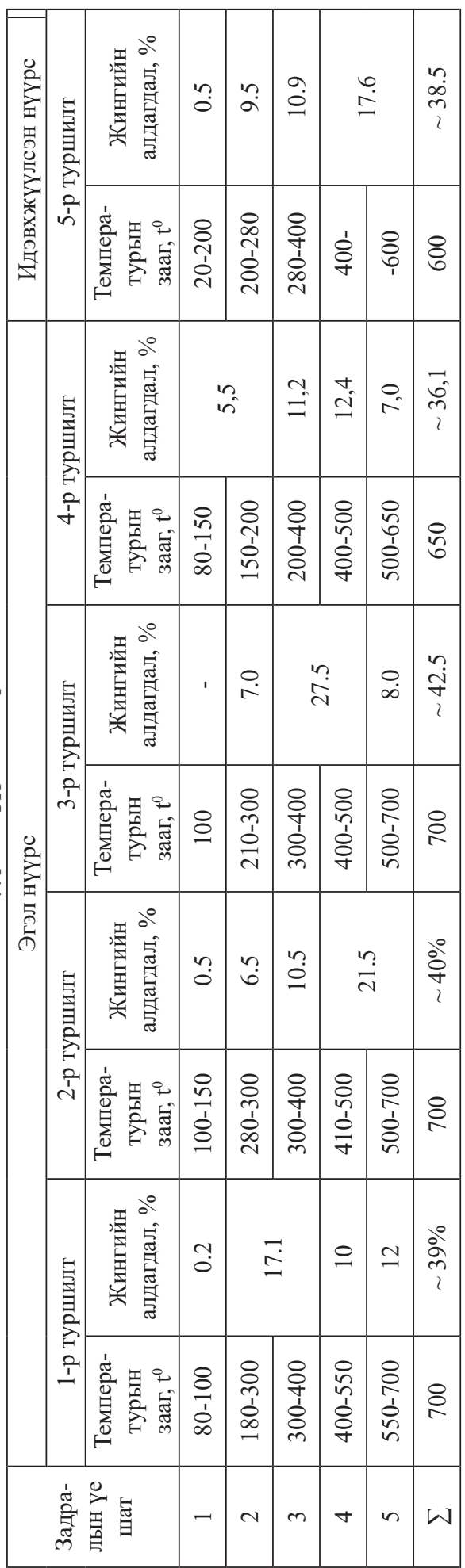

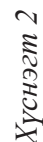

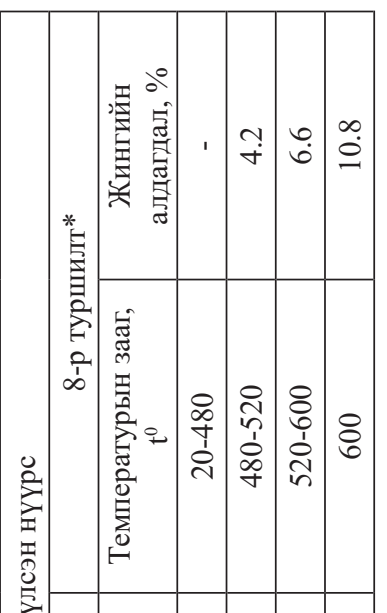

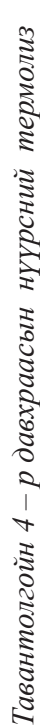

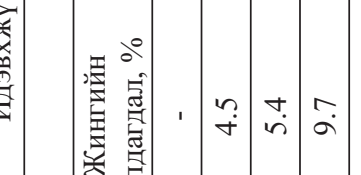

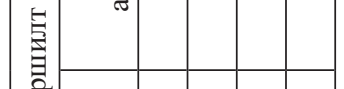

:

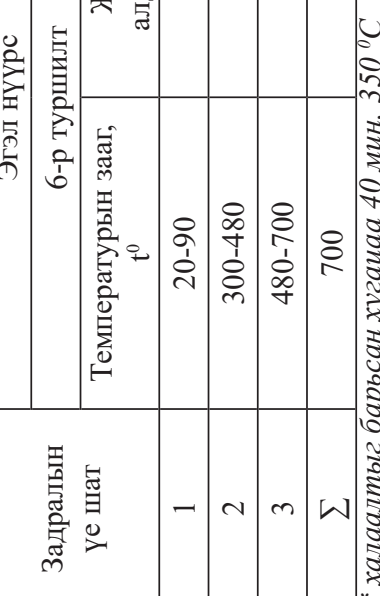

$-10-$ 
Хуснэгт 3

Тавантолгойн $8-p$ давхраасын нүүрсний термолиз

\begin{tabular}{|c|c|c|c|c|}
\hline \multirow{3}{*}{$\begin{array}{c}\text { Задралын үе } \\
\text { шат }\end{array}$} & \multicolumn{2}{|c|}{ Эгэл нүүрс } & \multicolumn{2}{|c|}{ Идэвхжүүлсэн нүүрс } \\
\hline & \multicolumn{2}{|c|}{ 9-р туршилт } & \multicolumn{2}{|c|}{ 10-р туршилт } \\
\hline & $\begin{array}{c}\text { Температурын } \\
\text { зааг, } \mathrm{t}^{0}\end{array}$ & $\begin{array}{c}\text { Жингийн } \\
\text { алдагдал, \% }\end{array}$ & $\begin{array}{c}\text { Температурын } \\
\text { зааг, } \mathrm{t}^{0}\end{array}$ & $\begin{array}{c}\text { Жингийн } \\
\text { алдагдал, \% }\end{array}$ \\
\hline 1 & $20-450$ & - & $300-500$ & 1.1 \\
\hline 2 & $450-480$ & 7.5 & $500-510$ & 6.6 \\
\hline 3 & $480-600$ & 7.1 & \multirow{2}{*}{$510-700$} & \multirow{2}{*}{13.3} \\
\hline 4 & $660-660$ & & & \\
\hline$\sum$ & 660 & $\sim 14.6$ & 700 & $\sim 20.9$ \\
\hline
\end{tabular}

Тавантолгойн IV давхраасын нүүрсний ДТА муруй (2, 3 - р зураг ) дээр 380, 500 ба $520{ }^{\circ} \mathrm{C}$ - д дулааны экзо (дулаан ялгаруулах ), 420, 590 ба $640{ }^{\circ} \mathrm{C}$ - д эндо (дулаан шингээх) илэрлүүд бүртгэгджээ. 2 р хүснэгт ба ТГ ба ДТГ муруйнуудыг (7,8 -p зураг) үзвэл, $90-100{ }^{\circ} \mathrm{C}$ - д шингээгдсэн чийгний ууршилттай холбоотой $0.8 \%$ орчим жингийн алдагдал гарчээ. Дээжийн жингийн тогтвортой аажим бууралт $300{ }^{\circ} \mathrm{C}-$ аaс эхлэн үргэлжилсэн байх бөгөөд $440-480{ }^{\circ} \mathrm{C}-\mathrm{ын}$ заагт хурд бага зэрэг нэмэгдсэн ба цаашдаа $700{ }^{\circ} \mathrm{C}$ хүртэл аажим буурсан байна. 2 - p хүснэгтээс үзвэл, дээжийн үндсэн задралын эхний үе буюу $300-480{ }^{\circ} \mathrm{C}$ - дахь жингийн бууралт $11.3 \%$, дараахи үе $480-700{ }^{\circ} \mathrm{C}-$ д $13.7 \%$, туршилтын бүхий л хугацаанд гарсан нийт алдагдал буюу дэгдэмхийн гарц 25.8 \% байна. Нягт таглаатай тигельд халаагдаж байгаа нүүрсний дээж 450 - 480 ${ }^{0} \mathrm{C}$ - д хөөж эхлэн эзлэхүүн тэлж тигле дээр хайлмал малгай үүсгэн бөссөн ба түүнийг хөргөхөд сараалж структур бүхий лав мэт төлөв байдалтай яггүй бөх хөөмөл биет үүссэн. Энэ нь нүүрс бөсөх / спекаемый / чанартайн баталгаа юм. Эхний туршилтаар идэвхжүүлсэн дээжийн жингийн алдагдал $600^{\circ} \mathrm{C}$ - аaс доош температурт бүртгэгдээгүй тул $300-350{ }^{\circ} \mathrm{C} 40$ мин бариад үргэлжлүүлж $600{ }^{\circ} \mathrm{C}$ халаах туршилт явуулсан. Энэ туршилтаар, барилтын дараагаас $480{ }^{\circ} \mathrm{C}$ хүртэлхи температурт дээжийн жин огцом буурсан нь ТГ ба ДТГ муруйнууд дээр (8 - p зураг) тодорхой бүртгэгдсэн байна. Жингийн бууралт хоёр үе шаттай, нэгдүгээр нь 480 - $520{ }^{\circ} \mathrm{C}$ - д $4.2 \%$ - ийн бууралттай, хоёрдугаар нь $520-600{ }^{\circ} \mathrm{C}$ - д $6.6 \%$ - ийн бууралттай явагдсан ажээ. Жингийн нийт алдагдал $10.8 \%$ болсон. Тавантолгойн VIII давхраасын эгэл нүүрсний термограммыг (9 - р зураг) үзвэл, дэгдэмхий хийнүүдийг ( $5 \%$ ) огцом тэсрэлтийн байдлаар ялгаруулж явагдсан эндо илрэл $450-490{ }^{\circ} \mathrm{C}$ - д гарсан байна. Хойшхи температурт термолиз жигд аажим явагдсан ба $600{ }^{\circ} \mathrm{C}$ хүртэлх жингийн алдагдал $14-15 \%$ хүрчээ. Дээжийн ДТА муруй дээр 310-390-410 ${ }^{\circ} \mathrm{C}$ - д экзо илрэл бүртгэгдсэн нь сонирхол татаж байгаа ч нэгэн утгаар тайлбарлахад төвөгтөй.

Энэ давхраасын дээжүүдтэй явуулсан бүхий л туршилтаар термолизийн хатуу үлдэгдэл тиглийг дүүргэн хөөж сүүлдээ нилээд нягтарч яггүй бөх хөөмөл биет болж хувирсан.

10 - р зураг, 3 - р хүснэгтээс үзвэл, идэвхжүүлсэн дээжийн үндсэн задралын эхлэл 470 - aac $500{ }^{\circ} \mathrm{C}$ - д мөн л тэсрэлтийн байдлаар, 4.6 - $6.6 \%$ ийн жингийн алдагдалтай явагдсан ба термолизийн бүхий л процесс дахь жингийн нийт алдагдал эцсийн температурээс хамаарч 11.9 - ээс $20.9 \%$ - ийн хооронд байна. ДТА муруйнуунууд дээр хоёр ч тод экзо илрэл гарсан ч ДТГ ба ДГ дээр тэдгээртэй холбоотой илэрлүүд ажиглагдаагүй. Энэ нь мөнөөх экзо илрэлүүд нь нүүрсний масс дахь хатуу фазад жингийн өөрчлөлтгүй явагддаг, нягтарших урвалуудтай холбоотойн баталгаа байж болох юм. 


\section{ДҮГНЭЛТ}

Багануурын нүүрсний задрал харьцангуй нам температур $180-210^{\circ} \mathrm{C}-$ д тэсрэлт байдлаар хий ялгаруулан эхэлдэг ба эндээс үндсэн задрал эхлэх $280-300^{\circ} \mathrm{C}$ хүртэл гарах жингийн алдагдал буюу ялгарах дэгдэмхийн гарц 7\% орчим байна. Харин туршилтын төгсгөлийн температур $700{ }^{\circ} \mathrm{C}$ хүртэл ялгарах дэгдэмхийн нийлбэр 36.1 - 41.5\% байв. Механоидэвхжүүлсэн нүүрсний задрал мөн л харьцангуй нам температур $180-200{ }^{\circ} \mathrm{C}$ - д эхэлж үндсэн задрал эхлэх хүртэлхи жингийн алдагдал 8 - $9 \%$, төгсгөлийн 600 ба $660{ }^{\circ} \mathrm{C}$ хүртэлхи алдагдал 38.5 - $42.0 \%$ хүрсэн.

Тавантолгойн нүүрсний ДТА муруй дээр 380, 500 ба $520{ }^{\circ} \mathrm{C}$ - д дулааны экзо (дулаан ялгаруулах ), 420, 590 ба 640 ${ }^{0} \mathrm{C}$ - д эндо (дулаан шингээх) илэрлүүд бүртгэгджээ. Дээжийн жингийн тогтвортой аажим бууралт $300{ }^{\circ} \mathrm{C}-$ аaс эхлэн үргэлжилсэн байх бөгөөд $440-480{ }^{\circ} \mathrm{C}-\mathrm{ын}$ заагт хурд бага зэрэг нэмэгдсэн ба цаашдаа $700{ }^{\circ} \mathrm{C}$ хүртэл аажим буурсан байна. 450 $480{ }^{\circ} \mathrm{C}-$ аас эхлэн эзлэхүүн тэлж сараалж структур бүхий лав мэт төлөв байдалтай яггүй бөх хөөмөл биет үүсгэн бөсдөг нь ажиглагдлаа. Энэ нь давхраасын нүүрсний бөсөх, коксжих чанартайн илэрхийлэл юм.

ДТА муруйнуунууд дээрхи экзо илэрлүүд нүүрсний масс дахь хатуу фазын нягтарших урвалуудтай холбоотой гэж Үзэв.

\section{Ашигласан бүтээлийн жагсаалт}

1. Ю.Д. Каминский, Ж.Дугаржав, Т.Е.Шоева, Б.Авид. Багануур, Тавантолгойн ордын нүурсний хими - бүтцийн төрх байдал, онцлог. Шинжлэх ухааны академийн мэдээ, 2012, №

2. D. A. Skoog, F. J. Holler, and T. A. Nieman, Principles of instrumental analysis, 5/e, Harcourt Publishers, 2001.

3. P. Gabbott, Ed., Principles and Applications of Thermal Analysis, Blackwell, 2008.

4. Ж.Дугаржав. Б.Авид, Ж.Нарангэрэл. Нүүрсний хими-технологийн судалгаа 40 жилд. Уул уурхайн хүрээлэнгийн 50 жилийн ойн эрдэм шинжилгээний бага хурлын илтгэлүүдийн эмхтгэл. 2009.

5. .Дугаржав, Б.Пүрэвсүрэн, Г.Шийрав, Ж.Намхайноров. Annual Scientific Reports of the ICCT,MAS, № 9 (35), 2008, p.28-34. 